\title{
Cultura Cultura
}

Revista de Historia Teoria das sldeias $\quad$ Revista de História e Teoria das Ideias

Vol. 25 | 2008

Varia

\section{Joana, metáfora da androginia papal}

Joan, Symbolic Papal Androgyny

\section{Hilário Franco Júnior}

\section{OpenEdition}

Journals

Edição electrónica

URL: http://journals.openedition.org/cultura/655

DOI: 10.4000/cultura.655

ISSN: 2183-2021

\section{Editora}

Centro de História da Cultura

\section{Edição impressa}

Data de publição: 1 Junho 2008

Paginação: 113-134

ISSN: 0870-4546

\section{Refêrencia eletrónica}

Hilário Franco Júnior, « Joana, metáfora da androginia papal », Cultura [Online], Vol. 25 | 2008, posto online no dia 01 outubro 2013, consultado a 20 abril 2019. URL : http://journals.openedition.org/ cultura/655; DOI : 10.4000/cultura.655 


\title{
Joana, metáfora da androginia papal*
}

\author{
Hilário Franco Júnior
}

Entre meados do século XI e meados do XVI circularam no Ocidente cristão vários relatos sobre uma suposta papisa Joana, que por ter sido considerada personagem histórica pôde ser utilizada pelos protestantes como prova da decadência moral da Igreja. Como reação, os católicos passaram a partir de então a negar sua veracidade. Nas últimas décadas do século XIX e primeiras do XX, os historiadores eclesiásticos explicaram-na como deturpação do texto de um cronista romano próximo ao ano mil. ${ }^{1}$ Aí estaria a origem do relato "risível", da "lenda indigna e odiosa", "ridícula" e "grotesca", cuja personagem é "simples produto da imaginação", "fruto da imaginação de cronistas sem outros episódios picantes".2

A historiografia positivista não percebia que a própria imaginação deve ser objeto de estudo da História, objeto central porque de certa forma presente em todos os outros. Ela não se perguntava mesmo porque aquele produto "da imaginação popular, tão facilmente criadora de lendas absurdas" tinha sido registrado pela cultura erudita, letrada e latina dos cronistas. ${ }^{3}$ Cerca de cem anos depois, sob perspectiva bem diferente, o tema

* Este artigo foi elaborado durante uma estada na École des Hautes Études en Sciences Sociales (Paris) enquanto professor-convidado, graças à proposição de Jean-Claude Schmitt, a quem muito agradecemos.

** Universidade de São Paulo.

1 Como BENTO DE SANTO-ANDRÉ DE SORATE Chronicon, ed. G. Zucchetti, Roma, Istituto Storico Italiano, 1920, fala da influência de uma mulher da alta aristocracia romana tanto sobre seu filho, o papa João XI (931-936), quanto sobre a cidade ("subiugatus est Roman potestative in manu femine": p. 161, linhas 3-4), alguns historiadores pensaram que o "povo" teria dado a ela o apelido de papisa, feminilizando o nome do pontífice: A. BIANCHI-GIOVINI, Esame critico degli atti e documenti relativi alla favola della papessa Giovanna, Milão, Civelli, 1845, p. 204; A. LAPÔTRE, L'Europe et le Saint-Siège à l'époque carolingienne. Le pape Jean VIII (872-882), Paris, Picard, 1895, pp. 366-367; C. DOUAIS, "La papesse Jeanne", Bulletin théologique, littéraire et scientifique (Toulouse), 9, 1897, pp. 219-220; F. VERNET, "Jeanne (La papesse)", em A. D'ALÈS (dir.), Dictionnaire apologétique de la foi catholique, Paris, Gabriel Beauchesne, 1911, vol. II, col. 1258; E. VACANDARD, "La papesse Jeanne", dans IDEM, Études de critique et d'histoire religieuse, Paris, Victor Lecoffre, 1923, vol. IV, pp. 37-38.

2 Respectivamente, J. J. I. DÖLLINGER, Die Papst-Fabeln des Mittelalters, Munique, Cotta, 1863, p. 4; DOUAIS, pp. 217, 220; LAPÔTRE, pp. 367 e 362; VACANDARD, p. 34 (citados na nota anterior).

3 VACANDARD, "La papesse Jeanne" (cit. n. 1), p. 34. De seu lado, LAPÔTRE, L'Europe (cit. n. 1), explica que um cronista muito ligado à corte papal não percebeu as incoerências cronológicas que negariam 
mereceu dois importantes estudos, que porém apenas tangenciaram o ponto de vista que agora nos interessa. ${ }^{4}$

Em linhas gerais trata-se de uma história simples, cuja estrutura não é afetada pela existência de diversas variantes, pois "a substância do mito não se encontra nem no estilo, nem no modo de narração, nem na sintaxe, mas na história que ali é contada", afirma Lévi-Strauss. ${ }^{5} \mathrm{O}$ relato básico fala em uma mulher de origem inglesa, porém nascida em Mogúncia, que acompanhou seu amante até Atenas, onde passou certo tempo, estudou e adquiriu grande sabedoria, graças à qual, em Roma, disfarçada de homem, fez rápida carreira eclesiástica e acabou por ser eleita papisa. Após algum tempo de pontificado ela engravidou e durante uma procissão pariu, morrendo no local, onde foi erguida uma pedra comemorativa ao inusitado evento. A partir de então, o trajeto da procissão papal foi alterado para evitar aquele local e para ser confirmado todo novo pontífice romano deveria sentar em duas cátedras com abertura no assento a fim que fosse verificada sua masculinidade.

Na busca de um sentido para esta narrativa, ela precisa a nosso ver ser examinada em três pontos centrais e articulados.

\section{A crença generalizada em Joana até o século XVI}

Todos os estudiosos concordam que até 1550 surgiram dezenas de versões daquela narrativa, com pouquíssimos autores tendo dúvidas quanto à historicidade de Joana. Ainda por volta de 1471, as Vitae pontificum romanorum encomendadas por Sisto IV continuavam a aceitar a existência de Joana, e até princípios do século XVII havia um busto dela entre as efígies papais da catedral de Siena. Já se disse mesmo que por quinhentos anos acreditou-se na papisa e isso teria continuado a acontecer não fosse a controvérsia

a existência de Joana porque "ele era de seu tempo" (p. 220), sem notar que isso significa aproximar produção erudita e "imaginação popular". É verdade que VERNET, "Jeanne" (cit. n. 1), depois de chamar a lenda de "repugnante" (col. 1261) e "estúpida" (col. 1262), afirma que ela ajuda "a penetrar na psicologia da Idade Média" (col. 1269), mas não tira proveito algum dessa observação. O problema historiográfico da papisa Joana é sobretudo um problema de método, como percebeu K. HERBERS, "Die Päpstin Johanna. Ein kritischer Forschungsbericht", Historisches Jahrbuch, 108, 1988, pp. 174$-194$.

4 Cf. D'ONOFRIO, La papessa Giovanna. Roma e Papato fra storia e leggenda, Roma, Romana Società Editrice, 1979 (que vê o episódio sobretudo como um elemento da história da cidade de Roma) e A. BOUREAU, La Papesse Jeanne, Paris, Aubier, 1988 (para quem a papisa é exemplo de um processo de produção intelectual de longa duração).

5 Anthropologie structurale, Paris, Plon, 1958, p. 232. 
gerada pela Reforma Protestante. ${ }^{6}$ No entanto, o marco inicial da história de Joana não é unânime. A primeira menção teria sido do cronista Mariano Scoto, em meados do século $\mathrm{XI}^{7}$ porém esse testemunho é contestado.

Seguindo a Quellenforschung da papisa começada por Döllinger, a tendência tem sido descartar essa fonte (e outras) argumentando que as passagens sobre Joana são interpolações. ${ }^{8}$ Sem entrar na tecnicidade deste dado, provavelmente correto, é preciso porém considerar que as interpolações medievais também são fontes, também expressam um certo estado da crença na época. Mais do que deturpar a "verdade" histórica, como pensavam os positivistas, as interpolações revelam certos aspectos dela. De forma geral o interpolador inventa um fato no sentido etimológico e medieval da palavra: ele "descobre" e registra uma informação que circula na sua época e que escapara ao texto no qual ele intervém. Ele preenche uma lacuna que não deveria existir. ${ }^{9} \mathrm{O}$ acréscimo não era considerado falsidade, e sim revelação de verdade oculta. Os medievais não acreditavam em determinado fato porque ele era interpolado; ao contrário, ele era interpolado porque se acreditava nele. ${ }^{10}$

6 BIANCHI-GIOVINI, Esame critico (cit. n. 1), p. 248. Concordam com isso VACANDARD, "La papesse" (cit. n. 1): "ninguém sonharia, nem no século XIII, nem no XIV, em contestar a existência da papissa" (pp. 22-23); e D'ONOFRIO, La papessa (cit. n. 4), para quem até Lutero os católicos haviam "tranquilamente aceito a papisa" (p. 111).

7 Chronicorum, ed. B. G. Struvius, Bibliotheca scriptores rerum germanicarum, lena, Felicis Bielcki, 1730, vol. I, p. 639.

8 O teólogo alemão (acompanhado depois por Lapôtre, Vernet, Vacandard e Boureau) argumenta que a história da papisa não aparece na edição G. Waitz, MGHSS 5, do texto de Mariano Scoto, e que também são acréscimos posteriores as menções feitas por Sigeberto de Gembloux e Oto de Freising (Die PapstFabeln, cit. n. 2, pp. 5-7). Quanto a este último cronista, VACANDARD (cit. n. 1) não é tão impositivo e pensa que a notícia sobre Joana foi "provavelmente" interpolada (p. 19). BIANCHI-GIOVINI (cit. n. 1), por sua vez, acredita que são autênticos os relatos de Scoto (pp. 48-52, 87, 199) e de Godofredo de Viterbo (p. 52), interpolado o de Sigeberto (pp. 54-55) e hesita a respeito do de Oto (p. 55). D'ONOFRIO (cit. n. 4) aceita a autenticidade daqueles três primeiros cronistas (p. 40). B. SCHIMMELPFENNIG, "Johannes", em Lexikon des Mittelalters, Munique, Ártemis, 1991, adota formulação cuidadosa e fala em "indicações desde o século XI de uma papisa sem nome" (vol. V, col. 527).

9 A crítica moderna durante séculos teve por modelo falso a Doação de Constantino, que o humanista Lourenço Valla mostrou em 1440 ser bem posterior aos fatos que ela supostamente descrevia. Mas ao longo da Idade Média aquele foi um documento legítimo, elaborado pela burocracia papal no século VIII para haver o registro de um fato inconteste na ótica da tradição eclesiástica. Ver naquele documento uma mera defesa dos interesses papais é anacronismo. Não é por casualidade, mas como produto de novo ambiente cultural, que o primeiro a duvidar do relato sobre Joana tenha sido em 1451 o humanista Enéas Sílvio Piccolomini, futuro papa Pio II.

${ }^{10}$ É significativo que a história de Joana, inserida na crônica de Martinho Polonês entre 1278 e 1312 (cf. DÖLLINGER, Die Papst-Fabeln, p. 11), tenha sido a partir de então incluída na versão oficial da história dos papas, o Liber Pontificalis, ed. L. Duchesne, Paris, De Boccard, 1955, vol. II, pp. XXVI-XXVII. 
A época em que Joana teria pontificado também é discutível: início do século VIII para um cronista, ${ }^{11}$ meados do século IX para a maioria ${ }^{12}$, princípios do $\mathrm{X}$ para outro ${ }^{13}$, fins do $\mathrm{XI}$ para alguns ${ }^{14}$. A duração do pretenso pontificado também é controversa, variando de dois anos, cinco meses e quatro dias (para Mariano Scoto e Bartolomeu de Lucca) até dezenove anos e dois meses (conforme Riccobaldo de Ferrara) ${ }^{15}$. Alguns cronistas não nomeiam o personagem, limitando-se a indicar que era mulher (como faz João de Mailly e a Chronica Minor), outros a chamam de Joanna (Mariano Scoto, Godofredo de Viterbo), outros a consideram mulher embora empreguem o masculino (Joannes em Sigeberto de Gembloux e Riccobaldo de Ferrara; lohannes em Martinho Polonês, no Flores temporum e em Gofredo de Courlon; Joanne em Bartolomeu de Lucca), fontes tardias dão-Ihe nome diferente (Agnes para João Huss) ${ }^{16}$. O título atribuído a ela oscilava entre papissa (Godofredo de Viterbo, João de Mailly) e pseudopapa (Chronica Minor). De um lado, essas indefinições não são estranhas, pois cronista algum escreveu a menos de dois séculos de distância dos supostos fatos. De outro lado, se "a Igreja até a Reforma crê e faz crer na realidade de um fato que parece comprometer sua reputação e que posteriormente ela

1 OTO DE FREISING, Chronicon, VII, em Germaniae historicum illustrium ab Henrico IV ad annum 1400, Frankfurt, Andreae Wecheli, 1585, vol. I, p. 163.

12 MARIANO SCOTO, Chronicorum (cit. n. 7) p. 639; SIGEBERTO DE GEMBLOUX, Chronographica, ed. Struvius (cit. n. 7), vol. I, p. 794; GODOFREDO DE VITERBO, Pantheon, PL 198, col. 1017 A; MARTINHO POLONÊS, Chronicon Pontificum et Imperatorum, ed. L. Weiland, MGHSS 22, p. 428, linhas 27-28; JACOPO DE VARAZZE, Chronica civitatis ianuensis, ed. G. Monleone, Roma, Istituto Storico Italiano per il Medio Evo, 1941, pp. 268-269; Flores temporum, ed. O. Holder-Egger, MGHSS 24, p. 243, linha 43; GOFREDO DE COURLON, Chronicon, ed. O. Holder-Egger, MGHSS 26, p. 614, linha 22; RICCOBALDO DE FERRARA, Historia Pontificum Romanorum, ed. L. A. Muratori, Milão, Palatinae, 1726 (Rerum Italicarum Scriptores, 9), col. 167 C; TEODORICO ENGELHUSIUS, Chronicon, ed. G. W. Leibnitz, em Scriptorum rerum brunsvicensium, Hanover, Foersteri, 1711, vol. II, p. 1065. Outro cronista do início do século XIV data Joana da segunda metade do século IX, mais precisamente de 884: BARTOLOMEU DE LUCCA, Historia ecclesiastica, XVI, 10, ed. Muratori, RISS vol. 11, col. 1013 D.

${ }^{13}$ Chronica minor, ed. O. Holder-Egger, MGHSS 24, p. 184.

14 JOÃO DE MAILLY, Chronica Universalis Mettensis, ed. G. Waitz, MGHSS 24, p. 514; ÉTIENNE DE BOURBON, Septem donis Spiritus sancti, em J. QUETIF e J. ECHARD, Scriptores ordinis praedicatorum recensiti [1719], Turim, Bottega d'Erasmo, 1961, vol. I, p. 367.

${ }^{15}$ Chronica, ed. G. F. de Lignamine, Roma, 1474 (que não pudemos consultar), citado por D'ONOFRIO, La papessa (cit. n. 4), p. 35. Enquanto neste texto ele data o início do pontificado de 848, em Historia Pontificum Romanorum (cit. n. 12) repete as informações de Mariano Scoto quanto à data (854) e à duração. E em outro ainda, o mesmo cronista mantém a data e diminui quatro dias o tempo do pretenso pontificado, que diz não estar no catálogo papal por ter sido de uma mulher (Compilatio chronologica, ed. Muratori, RISS vol. 9, col. 236 D).

${ }^{16}$ C. J. HEFELE, Histoire des conciles d'après les documents originaux [1916], trad., Hildesheim/Nova York, Georg Olms, 1973, vol. VII-1, p. 154. 
denunciará como vil e baixa calúnia protestante ou anticlerical", ${ }^{17}$ por que não há testemunhos anteriores de um fenômeno que mais tarde chamaria tanto a atenção?

A resposta de Ignaz Von Döllinger é que o relato sobre a papisa foi construído por dominicanos (como os cronistas João de Mailly, Étienne de Bourbon e Martinho Polonês) e franciscanos (como os autores anônimos da Chronica Minor e da Flores Temporum) devido à antipatia recíproca entre eles e Bonifácio VIII; desde então "os historiadores das ordens religiosas aproveitaram todas as ocasiões para introduzir, com maior ou menor malícia, o escândalo nas suas obras sobre o papado".18 É verdade que no século XIII ocorreram problemas entre as Ordens Mendicantes e o papado, porém eles não podem ser generalizados. Apenas a corrente franciscana purista, radicalmente ligada às suas raízes (os chamados franciscanos espirituais), foi combatida pela Igreja, enquanto os franciscanos conventuais continuaram a ocupar postos importantes na hierarquia eclesiástica e nas universidades. Os dominicanos, por sua vez, eram célebres por sua fidelidade (os rivais explicavam a etimologia de seu nome como domini cani, "cães do Senhor") ao papado, o que Ihes valeu a direção da então recém-criada Inquisição e a predominância na elaboração teológica. Um exemplo da importância dos dominicanos na cúria romana é Martinho Polonês (1230-1278), capelão de cinco papas e justamente o principal responsável pela difusão da lenda da papisa.

A resposta de Alain Boureau está na crise que o papado conheceu desde 1292-1294 (quando o trono pontifício ficou vago por 27 meses), acentuada em 1303 (quando Bonifácio VIII foi aprisionado a mando do rei francês Filipe IV) e sobretudo aprofundada em 1307-1377 (quando os papas ficaram exilados em Avignon) e em 1378-1415 (quando os cardeais discutiram os limites do poder papal e cresceu a idéia de que o Concílio devia ser superior ao sumo pontífice). Nessa interpretação, a figura de Joana teria sido uma crítica à monarquia pontifícia, que do ponto de vista de certos grupos, eclesiásticos e laicos, ganhara poder excessivo no período entre Gregório VII (1073-1085) e Inocêncio III (1198-1216). A papisa seria produto de ritual paródico, de contra-liturgia dirigida à nova concepção de papado, mais fechado e dominador, que excluía a comunidade romana do poder e dos atos litúrgicos ligados ao surgimento de cada novo pontífice. ${ }^{19}$

17 BOUREAU, La Papesse (cit. n. 4), pp. 120-121.

18 DÖLLINGER, Die Papst-Fabeln (cit. n. 2), pp. 16-18, análise que não deixa de ter relação com a posição eclesiológica do autor, que desde 1843 se opunha aos jesuítas em especial e às Ordens religiosas em geral, desnecessárias à Igreja, segundo ele. A tese de crítica dominicana ao papado foi aceita por R. e D. PARDOE, A papisa Joana [1988], trad., São Paulo, Ibrasa, 1990, pp. 85-87, 142.

19 BOUREAU, La Papesse (cit. n. 4), pp. 83-115. C. BLASCO, Diatriba de Joanna papissa sive de ejus fabulae origine, Nápoles, Abbaziana, 1778, também vira no mito de Joana uma sátira contra as Falsas Decretais 
Não se pode negar a pertinência dessa explicação institucional do mito da papisa, mas devemos vê-la também por um plano mais amplo, sem o qual aquela narrativa não teria tido o sucesso que teve, já que como o próprio Boureau observa com razão "um episódio não sobrevive se não ganha sentido, se não pode ilustrar uma verdade geral". ${ }^{20}$ Mesmo que se considere que o primeiro cronista do tema tenha sido João de Mailly, estaríamos décadas antes da crise pontifical. ${ }^{21}$ Mais importante, nada indica que Joana tenha sido um "episódio", e exatamente por isso ele não apenas "sobrevive" como tem longa vida em muitas versões e "durante dois ou três séculos todo mundo crê na realidade do episódio". ${ }^{22} \mathrm{Na}$ origem da narrativa havia um rumor (ut fatentur Romani diz o cronista de Erfurt, ut asseritur escreve Martinho Polonês, ut dicitur afirmam Roberto de Uzès, Gofredo de Courlon e Bartolomeu de Lucca) que deveria expressar a "verdade geral" a que se refere Boureau. Mas qual?

\section{A inscrição da pedra comemorativa}

Buscando as razões que permitiram o surgimento daquele rumor, chegamos ao nosso segundo ponto. No local em que Joana pariu havia uma inscrição com seis $\mathrm{P}$, que os cronistas medievais não interpretaram como condenação do suposto fato; então por que a partir do século XII os pontífices recusaram-se a passar por ali? As explicações historiográficas insistem sobre a estreiteza da rua, ${ }^{23}$ o que não nos parece suficiente. A questão talvez deva ser invertida: por que inicialmente a procissão vinda de Latrão virava à esquerda naquela estreita rua (vicus Papisse), se o trajeto liturgicamente mais lógico indicava virar à direita e passar diante da igreja de São Clemente? É evidente que a economia de poucas

de meados do século IX. D'ONOFRIO, La papessa (cit. n. 4), propõe que a história da papisa teria sido deturpação jocosa feita pelos cônegos do Vaticano contra a idéia de Mater Ecclesia que beneficiava os cônegos de Latrão (pp. 240-241). De fato, entre 496 e 824 apenas três dos 49 papas existentes não foram sepultados no Vaticano, próximos à tumba de São Pedro, enquanto mais tarde cresceu nesse papel a importância de Latrão, que no século XII recebeu a tumba de dez dos quinze pontífices da época e tornou-se "a verdadeira residência papal" na expressão do Liber Pontificalis (cit. n. 10), II, p. 305.

${ }^{20}$ A. BOUREAU, "La papesse Jeanne. Fonctions et formes d'une légende au Moyen Âge", Comptes rendus de l'Académie des Inscriptions et Belles-Lettres, 1984, p. 449.

${ }^{21}$ A datação do cronista adotada por Boureau, por volta de 1250, é a tradicional (proposta por exemplo por A. POTTHAST, Bibliotheca Historica Medii Aevii, Berlim, W.Weber, 1896, p. 241), mas tanto ele quanto Döllinger reconhecem que o relato do dominicano baseava-se em tradições orais anteriores. Se retrocedermos a data para 1225, como faz D'ONOFRIO, La papessa (cit. n. 4), p. 43, a crônica de Mailly estaria ainda mais afastada da crise pontifical de fins da Idade Média.

22 BOUREAU, La Papesse (cit. n. 4), p. 9.

${ }^{23}$ VERNET, "Jeanne" (cit. n. 1), col. 1260; D'ONOFRIO, La papessa (cit. n. 4), p. 229; BOUREAU, La Papesse (cit. n. 4), p. 102. 
dezenas de metros não é resposta aceitável para a religiosidade medieval e sua tendência peregrinatória. Talvez o que se evitasse naquele contexto ritual fosse a própria igreja de São Clemente. Hipótese aparentemente absurda, mas que pode se revelar útil se considerarmos não a topografia geral do local, e sim sua topografia sacra.

De fato, aquela igreja nasceu em fins do século III ou começo do IV da cristianização de um dos muitos templos existentes na cidade de Roma dedicados ao deus iraniano Mitra, o principal concorrente do cristianismo. A igreja foi ampliada e reformada várias vezes ao longo dos séculos seguintes até ser reconstruída entre 1099 e 1128, depois de arruinada pelo incêndio provocado pelos normandos em 1084. Essas diferentes e freqüentes intervenções provavelmente não deixaram que se perdesse a lembrança de que a igreja de São Clemente fora construída no local de um mithraeum..$^{24}$ Mas se estas obras descobriram vestígios antigos e redespertaram suas origens pagãs, o que mudou alguns anos mais tarde? Por que um texto oficial das cercanias de 1140 determinou que a procissão da segunda-feira de Páscoa, saída de Latrão, tomasse a rua dos Quatro Coroados e virando à direita passasse diante da igreja de São Clemente, para mais à frente pegar a esquerda na rua Labicana em direção ao Coliseu e ao Vaticano ${ }^{25}$ ? A resposta talvez esteja na reabilitação de uma característica comum tanto ao culto mitraico quanto ao cristianismo primitivo, e que exatamente por esses ecos pagãos tinha sido escamoteada por muito tempo, sem contudo desaparecer, podendo reemergir com força no contexto do "renascimento" do século XII - a androginia. ${ }^{26}$

${ }^{24} \mathrm{O}$ número de mithraea existente em Roma foi calculado em 45, de um total, em momentos diferentes, de cem: M. J. VERMASEREN, De Mithradienst in Rome, Nimegue, Centrale, 1951, pp. 89-95, 149. Para a história do edifício anterior ao século XII, F. GUIDOBALDI, San Clemente. Gli edifici romani, la basilica paleocristiana e le fasi altomedievali, Roma, S.Clementem, 1992 (San Clemente Miscellany, IV-1). Como uma das mais intensas intervenções ocorreu na época de Leão IV (847-855), quando se trabalhou na decoração e na estrutura daquele edifício (GUIDOBALDI, pp. 205-208), pode-se perguntar se isso teria tido alguma relação com a atribuição do pontificado de Joana logo a seguir ao daquele papa, como fizeram os vários cronistas citados na nota 12.

25 "[...] descendit in via Maiorem sub arcu formae, et dextra manu ante Sanctum Clementem declinans in laevam iuxta Coloseum [...] ascendit ad Vaticanum in basilica Beati Petri apostoli", conforme o Ordo romanus, redigido por volta de 1140: R. VALENTINI e G. ZUCCHETTI (eds.), Codice topografico della città di Roma, Roma, Istituto Storico Italiano per il Medio Evo, 1946, vol. III, pp. 217-218.

${ }^{26}$ Quanto à presença dela no cristianismo primitivo, W. A. MEEKS, "The image of the androgyne: some uses of a symbol in earliest christianity", History of Religions, 13, 1974, pp. 165-208. O primitivo caráter andrógino de Mitra (G. WIDENGREN, Les Religions de I'Iran [1965], trad., Paris, Payot, 1968, p. 144) pode ter sido reforçado na versão greco-romana da divindade por influência platônica, sobretudo do Timeu (R. MERKELBACH, “Die Kosmogonie der Mithrasmysterien”, Eranos Jahrbuch [Zurique], 34, 1965, pp. 219-267). De qualquer forma, ele é atestado na iconografia (L. A. CAMPBELL, Mithraic iconography and ideology, Leiden, Brill, 1968, pp. 25-28, 37-38, 66-68, 169-170, 248-249) e revela traço importante da 
O ressurgimento desse antigo tema no Ocidente cristão medieval foi provavelmente estimulado pelo aceleramento das transformações sociais que ocorriam desde o século anterior. No plano institucional, a crescente diferenciação imposta pela Reforma Gregoriana entre os segmentos eclesiástico e laico criava neste último o sentimento de que o comportamento daquele, devido ao celibato e ao uso da batina, era andrógino, como sugere a denominação laica de "homem grávido", atribuída a todo eclesiástico. ${ }^{27}$ No plano doutrinário, o século XII redescobriu e revalorizou João Escoto Erígena, e com ele as especulações sobre o caráter andrógino da Divindade. ${ }^{28}$ Apesar de a Igreja medieval ter continuado a excluir a mulher do sacerdócio e mesmo do contato com as coisas sagradas (ela não podia tocar a hóstia, os vasos do altar, as vestes sacerdotais), crescia a importância concedida à Virgem, que de certa forma passava a compor uma espécie de Quaternidade na qual o elemento feminino ombreava os masculinos Pai, Filho e Espírito Santo. ${ }^{29}$ No plano cultural, a cidade de Roma sentiu no século XII grande fascinação por elementos vindos da Antiguidade, como exemplificam na igreja de São Clemente tanto

mentalidade da época (M. MESLIN, "Réalités psychiques et valeurs religieuses dans les cultes orientaux (I-IV siècles)", Revue historique, 512, 1974, pp. 302-304).

27 R. ZAPPERI, L'Homme enceint [1979], trad., Paris, PUF, 1983.

${ }^{28}$ E. JEAUNEAU, "Guillaume de Malmesbury, premier éditeur anglais du Periphyseon" [1980], em IDEM, Études Érigéniennes, Paris, Études Augustiniennes, 1987, p. 490, fala mesmo em "renascimento erigeniano" no século XII (p. 149), o que é bem ilustrado pela influência da obra do irlandês sobre a de um dos mais populares autores da época, cf. P. LUCENTINI, "La Clavis physicae di Honorius Augustodunensis e la tradizione eriugeniana nel secolo XII", em R. ROQUES (dir.), Jean Scot Erigène et l'histoire de la philosophie, Paris, CNRS, 1977, pp. 405-414.

${ }^{29}$ O conceito de Quaternidade divina estava presente no mitraísmo (o masculino Mitra e uma feminina deusa tricéfala) segundo um apologista cristão de meados do século IV: JULIUS FIRMICUS MATERNUS, L'Erreur des religions païennes/De errore profanarum religionum, V, 1-2, ed.-trad. R. Turcan, Paris, Belles Lettres, 1982, pp. 85-86. Implícito no cristianismo desde os gnósticos (cf. C. G. JUNG, Estudos sobre o simbolismo do si-mesmo [1976], Petrópolis, Vozes, 1982, pp. 240-241 et passim), ele tendeu a ser explicitado a partir do século XII por meio de uma certa "divinização" da Virgem (J. LE GOFF, Le Dieu du Moyen Âge, Paris, Bayard, 2003, pp. 46-47). No século XIII, Joaquim de Fiore acusou mesmo Pedro Lombardo de ter interpretado a Divindade mais como Quaternidade do que como Trindade ("Concilium Lateranensis IV", cap. II, em Sacrorum Conciliorum Nova et Amplissima, ed. J.-D. Mansi, Veneza, Antonio Zatta, 1778, vol. 22, col. 981-984). A rigor, a sensibilidade quaternária existia também em Bizâncio, onde a Virgem ocupava há mais tempo e mais intensamente um lugar privilegiado. Além disso, não se pode esquecer, as especulações teológicas sobre a androginia divina eram quase todas de origem oriental. Desta forma, não é de estranhar que lá tenha surgido, no século IX, uma tradição sobre um patriarca-mulher, transmitida ao Ocidente por uma crônica anônima de fins do século X (Chronicon salernitanum, 16, ed. G. H. Pertz, MGHSS 3, p. 481, linhas 1-6) e referida em 1053, portanto contemporaneamente a Mariano Scoto, pelo papa Leão IX em carta ao patriarca Miguel Cerulário (Epistolae, C, 23, PL 143, col. 760 C; HEFELE, Histoire des conciles, vol. IV-2, p. 1095). LAPÔTRE, L'Europe (cit. n. 1), pp. 363-365, pensa que nessa lenda bizantina esteve a origem da lenda da papisa. 
os mosaicos inspirados naqueles feitos nos séculos IV-V em Latrão, quanto o trono pontifical colocado na abside e elaborado com elementos de épocas anteriores encontrados na própria igreja. ${ }^{30}$

A interpretação que os cronistas deram à inscrição com seis $\mathrm{P}$, existente no lugar onde Joana teria morrido de parto, parece confirmar a hipótese da "reação folclórica" e das suas ainda inexploradas expressões andróginas. ${ }^{31}$ A suposta pedra tumular da papisa seria, propôs Döllinger, uma prosaica e antiga oferenda ao deus Mitra: Papirius (nome do doador), Patri Patrum (título do sacerdote de Mitra) Propria Pecunia Posuit (pôs [essa pedra] a suas próprias custas). ${ }^{32}$ Mas o entendimento medieval era diferente: "Pedro, Pai dos pais, propague o parto da papisa", segundo a transcrição de João de Mailly. Ou seja, aquele parto não era condenável. Ele não deveria ser escondido, pelo contrário, deveria ser eternizado na pedra, pois confirmava o caráter andrógino do ocupante do trono de Pedro. ${ }^{33}$ Lembremos que o patrono daquela igreja, Clemente, tinha sido o quarto papa; de acordo com a tradição, foi várias vezes considerado "apóstolo" e atribuía-se a ele um texto de meados do século II que parece sugerir a androginia de Cristo. ${ }^{34}$ Ou seja, nem o primeiro redator do Liber Pontificalis, em princípios do século $\mathrm{VI}$, nem seus continuadores

${ }^{30} \mathrm{H}$. TOUBERT, "Le renouveau du paléochrétien à Rome au début du XIIe siècle" [1970], em IDEM, Un art dirigé. Réforme grégorienne et iconographie, Paris, Cerf, 1990, pp. 268-310; R. KRAUTHEIMER, Rome, portrait d'une ville, 312-1308 [1980], trad., Paris, Librairie Générale Française, 1999, pp. 441-443, 445, 477-479, 482-484; H. BLOCH, "The new fascination with ancient Rome", em R. L. BENSON e G. CONSTABLE (eds.), Renaissance and renewal in the twelfth century [1982], Toronto, University of Toronto Press, 1991, pp. 615-636; F. GANDOLFO, "Reimpiego di sculture antiche nei troni papale del XII secolo", Atti della Pontifícia Accademia Romana di Archeologia, 47, 1974-1975, pp. 203-218.

31 Mesmo o grande livro de A. PARAVICINI BAGLIANI, // corpo del papa, Turim, Giulio Einaudi, 1994, não aborda o problema apesar de ter como eixos a corporeidade do papa sempre ligada de alguma forma à natureza de sua função e a premissa de que o corpo do pontífice é elemento fundamental para uma história mais completa do papado (p. XX). A noção de "reação folclórica" foi proposta por J. LE GOFF, "Culture cléricale et traditions folkloriques dans la civilisation mérovingienne" [1967], em IDEM, Pour un autre Moyen Âge, Paris, Gallimard, 1977, p. 233, n. 26.

32 DÖLLINGER, Die Papst-Fabeln (cit. n. 2), p. 28.

${ }^{33}$ É verdade que o "Petre, Pater Patrum, Papisse Prodito Partum" de João de Mailly parece ter sido invertido por Étienne de Bourbon (cit. n. 14): "Parce, Pater Patrum, Papisse Prodere Partum", isto é, "Evite, Pai dos pais, revelar o parto da papisa". No entanto, parce além de flexão verbal de parcere ("evitar"), pode ser o advérbio "com cuidado", "adequadamente", o que daria à frase o sentido de "Revele com cuidado, ó Pai dos pais, o parto da papisa".

${ }^{34}$ Ele é apóstolo para CLEMENTE DE ALEXANDRIA, Stromata, IV, 17, PG 8, col. 1311 A. Para o Liber Pontificalis (cit. n. 10), IV, vol. I, p. 123, ele é autor do apócrifo que vê no texto bíblico "Deus fez o homem macho e fêmea" uma referência a Cristo como sendo o macho e à Igreja como sendo a fêmea, mas também "o corpo de Cristo" (Second Epistle of Clement to the Corinthians, XIV, 2, ed-trad. K. Lake, em The Apostolic Fathers, Cambridge [Mass.]/Londres, Harvard University Press/William Heineman, 1985, vol. I, pp. 150 151), o que insinua que Nele há tanto o masculino quanto o feminino. 
que mantiveram aquela atribuição (hic fecit duas epistolas, quae catholicae nominantur) nos séculos seguintes, parecem ter se incomodado com a insinuação da carta pseudoclementina, estendível aos sucessores terrenos de Cristo, os papas.

\section{As cadeiras de mármore furadas}

Alcançamos assim o terceiro ponto de nossa análise. Logo após a eleição papal, que não tinha local determinado para ocorrer, o escolhido dirigia-se ao palácio de Latrão, onde se desenvolvia a cerimônia destinada a empossá-lo na função. ${ }^{35}$ Lá, no fundo da abside, atrás do altar da basílica, ele sentava-se na sedes patriarchalis que marcava sua condição de bispo de Roma. A seguir, acompanhado pelos cardeais, ia até o pórtico ocupar no lado esquerdo da entrada principal a cadeira de mármore branco conhecida por sedes stercoraria porque nela o papa recitava o versículo bíblico "et de stercore erigens pauperem". ${ }^{36} \mathrm{Ali}$ ele era apresentado ao povo e então aclamado, ato que confirmava legalmente a eleição. Minutos depois ele se levantava, entrava novamente na basílica em direção ao primeiro andar do palácio e diante da capela de São Silvestre sentava-se nas sedes porphyreticae, duas cátedras de mármore vermelho com amplo recorte no assento.

Estas cadeiras, diz Cesare D'Onofrio, eram antigas sellae obstetricae de imperatrizes romanas e o uso delas naquela cerimônia servia para indicar que o pontífice representava a Mater Ecclesia, a Igreja Romana que tinha primado sobre todas as outras Igrejas cristãs; daí na segunda metade do século XII ter se colocado na fachada da basílica de São João Latrão a inscrição "mãe e cabeça de todas as Igrejas". Desta forma, "não foi a suposta papisa que levou ao uso (como queria a lenda) das cadeiras furadas a fim de verificar previamente o sexo do neo-eleito, mas, ao contrário, foi a preexistência de tais cadeiras com seu (incompreendido) ritual que fez nascer a lenda de um papa mulher e mãe". ${ }^{37}$ As referidas cadeiras, ele acrescenta, não foram chamadas de porphyreticae devido ao seu material que lembrava o pórfiro, pedra de imperadores. Como afirmaram

35 Liber Censuum, LVIII, 78-79, ed. P. Fabre e L. Duchesne, Paris, Fontemoing, 1905, vol. I, pp. 311-312.

36 Salmo CXII, 7; 1 Samuel, II, 8. O pequeno buraco, do tamanho de uma moeda, que essa cadeira apresenta bem no centro do assento não faria referência à atividade defecativa que o ser humano não possuía no Éden e ganhou com a Expulsão (cf. I/ combattimento di Adamo, 41, ed.-trad. A. Battista e B. Bagatti, Jerusalém, Franciscan Printing Press, 1982, pp. 110-112)? Talvez porque a utilização ritual da sedes stercoraria tivesse sido introduzida por Leão IV (cf. Liber Pontificalis, CV, 11, p. 108), alguns cronistas confundiram as várias cadeiras empregadas na cerimônia e colocaram o suposto pontificado de Joana logo a seguir ao daquele papa (cf. nota 12).

37 D'ONOFRIO, La papessa (cit. n. 4), p. 162. Em linhas gerais essa idéia é aceita por A. PARAVICINI BAGLIANI, II trono di Pietro, Roma, La Nuova Italia Scientifica, 1996, pp. 20-21, para quem, quando a cerimônia lateranense praticada desde fins do século XI deixou de ser compreendida no século XIII, deu surgimento 
Liutprando de Cremona em meados do século X e Ana Commena no início do XII, o título dos príncipes bizantinos, "porfirogênetas", significava "nascidos no palácio Porphyria", construído em Bizâncio por Constantino seguindo o modelo de Latrão, doado por ele ao pontífice romano. ${ }^{38}$

Alain Boureau rejeita tal hipótese e alegando a Gestalttheorie afirma que pouco importa a forma das cadeiras de mármore, e sim seu papel simbólico. Este seria o de cadeiras curuis, símbolo do poder dos cônsules e pretores na Roma antiga. Baseando-se em uma passagem do Liber Pontificalis que chama de curules as cátedras furadas usadas na cerimônia de 1099, ele acredita que, por fazerem alusão à república romana, elas seriam expressão de resistência às pretensões centralizadoras do Papado, estariam "encarregadas de marcar simbolicamente uma transação cerimonial entre a monarquia pontifical e a oligarquia cardinalícia." Elas não poderiam fazer referência a uma suposta função maternal da Igreja porque esta possuía papel mais de protetora que de parturiente: aliás, pergunta Boureau, de quê a Igreja poderia estar grávida? Assim, ele conclui que a imagem do papa é etimológica e historicamente paternal, masculina, não se confunde com a da Igreja (na qual reconhece porém "um estatuto supra-sexual, de andrógino masculino"): esta é mulher e mãe, aquele é homem e pai. ${ }^{39}$

Por caminhos diferentes, aqueles dois autores tangenciaram portanto o que nos parece o ponto central - Joana como metáfora da androginia pontifical -, mas acabaram por não explorá-lo. O fato de as cadeiras pórfiras serem duas foi simplesmente deixado de lado por D'Onofrio, o que tanto Michele Maccarrone quanto Alain Boureau perceberam, propondo explicações simbólico-institucionais. O primeiro deles, seguindo Joseph Deér, viu-as como reflexo da imitatio imperii que teria levado o papado a buscar um modelo em Constantinopla, onde em certos ritos oficiais usavam-se dois tronos imperiais. ${ }^{40} \mathrm{O}$ segundo afirmou que aquelas cadeiras eram curuis porque estas "estavam sempre em par" e porque no contexto de fins do século XI "precisava-se de cadeiras curuis". Ele reconhece entretanto que o redator do Liber Pontificalis não se refere mais a elas como curules quando de sua segunda utilização ritual, em 1124, interessando-se apenas pela forma delas (definida como sygmae, por semelhança com esta letra grega), enquanto em 1189

à pretensa verificação do sexo papal. Ambos negam, portanto, BIANCHI-GIOVINI, Esame critico (cit. n.

1), que vê no rito de verificação uma fábula nascida da preexistente crença na papisa (p. 183).

${ }^{38}$ D'ONOFRIO, La papessa (cit. n. 4), pp. 169-170.

39 BOUREAU, La Papesse (cit. n. 4), pp. 67, 48 (cf. também pp. 336-340), 57-62.

40 J. DEÉR, The Dynastic Porphyry Tombs of the Norman Period in Sicyly [1956], trad., Cambridge (Mass.), Harvard University Press, 1959, p. 145; M. MACCARRONE, "La 'cathedra' sancti Petri. Da simbolo a reliquia", Rivista di Storia della Chiesa in Italia, 39, 1985, pp. 402-403, 406-407. 
e 1192 para o Liber Censuum importa apenas o material de que eram feitas. Ou seja, o sentido anti-absolutista das cadeiras acabou por se perder. ${ }^{41}$

Mais importante do ponto de vista epistemológico, julgamos problemático argumentar que a função simbólica independe da forma, pois cada cultura estabelece à sua maneira, mas sempre estabelece, uma relação estrutural entre conteúdo e forma, esta revelando aquele, aquele dando sentido a esta. Logo, é difícil aceitar a função simbólica unicamente masculina do pontífice romano. Maccarrone admite que a lgreja tem função parturiente ao gerar novos filhos no batismo, porém exclui desse processo o papa, esposo da lgreja que "não podia substituí-la na função da maternidade", 42 por não levar em conta que, se explicitamente o papa é o esposo, muitas vezes implicitamente é a própria Igreja. Enquanto D'Onofrio interpreta como postura parturiente as referências documentais ao fato de o papa ficar nas cadeiras pórfiras "sentado em posição deitada", Maccarrone argumenta que se tratava de simples repouso, já que em fins do século XII aquela cerimônia tornara-se muito longa porque "tinha ganhado uma maior solenidade litúrgica".43 Ora, exatamente por isso é pouco plausível que no meio daquela cerimônia o pontífice tivesse de descansar, e em duas cadeiras idênticas, colocadas a poucos metros uma da outra. Além disso, se o pretenso repouso papal durante a cerimônia tornara-se necessário em fins do século XII segundo Maccarrone, por que existia desde o X conforme afirma o mesmo estudioso?

Contra a hipótese de as cátedras de Latrão serem parturientes, Maccarrone e Boureau preferem a postura tradicional que as vê como cadeiras de banho. ${ }^{44} \mathrm{O}$ erudito italiano

41 BOUREAU, La Papesse (cit. n. 4), pp. 64-65, 74-75. Depois de interpretar as cadeiras curuis de Latrão como negação do cesarismo do papa (p. 67), ele informa que desde o século VIII o pontífice era após a eleição saudado naquele palácio como senhor universal, habitando ali o primeiro andar, acima da basílica local (pp. 78-79). Parece, portanto, que a herança constantiniana superava a petrina, e então se pode pensar na interpretação inversa: mesmo que as cadeiras de Latrão fossem funcionalmente curuis, estariam lá para proclamar a superioridade da monarquia pontifícia sobre a república romana. Não eram as cadeiras que davam sentido imperial à residência do papa, mas o inverso.

42 MACCARRONE, "La cathedra” (cit. n. 40), p. 405.

43 D'ONOFRIO, La papessa (cit. n. 4), pp. 152-168; MACCARRONE, "La cathedra" (cit. n. 40), pp. 402, 403, n. 198. A fonte de 1192 fala em "sedere debet, ac si videatur inter duos lectulos jacere" (Liber Censuum [cit. n. 35], LVIII, 79, vol. I, p. 312), o cerimonial de Gregório X, de 1273, em "iacere, quam sedere" (81, ed. M. Dykmans, em Le Cérémonial papal de la fin du Moyen Âge à la Renaissance, Bruxelas/Roma, Institut Historique Belge de Rome, 1977, vol. I, p. 179), mesma expressão de Le Pontifical de la Curie romaine au XIII siècle, XIII B, 52, ed. M. Andrieu, trad. M. Goullet, G. Lobrichon e E. Palazzo, Paris, Cerf, 2004 , p. 116). Sobre a complexa história textual dos cerimoniais romanos, B. SCHIMMELPFENNIG, Die Zeremonienbücher der römischen Kurie im Mittelalter, Tübingen, Niemeyer, 1973, pp. 1-16, 30-35.

${ }^{44}$ O ponto de partida deles é B. de MONTFAUCON, Diarum italicum, sive Monumentorum veterum, bibliothecarum, musaeorum, etc, Paris, Joannem Anisson, 1702, p. 137, seguido depois por E. SAGLIO, "Balneum, Balneae", em Ch. DAREMBERG e E. SAGLIO (dir.), Dictionnaire des antiquités grecques et romaines, Paris, Hachette, 1877, vol. I, p. 662, fig. 768; Ph. LAUER, Le Palais de Latran. Étude historique et archéologique, 
pondera que, "se na origem elas tinham sido cadeiras de parto, isso não explica porque eram duas, não apenas uma, como requer o ofício, nem porque eram idênticas e complementares, usadas para a cerimônia da entrega ao papa das chaves e da férula, símbolos e funções que não têm nada a ver com o ato e o símbolo da parturiente" ${ }^{45}$ É verdade, contudo a mesma coisa pode-se dizer em relação à hipótese de cadeiras de banho. Fossem uma coisa ou outra, elas eram duas possivelmente por homologia com as duas espadas e as duas coroas da simbólica de poder pontifício, isto é, pode-se pensar que as cadeiras pórfiras faziam parte daquilo que Agostino Paravicini Bagliani chama de "história metafórica que sustenta a pretensão papal à universalidade de seu poder". ${ }^{46}$ Explicação verossímel, porém demasiado ampla.

A cerimônia lateranense das cadeiras furadas é tradicionalmente interpretada como tomada de posse do palácio de Latrão, mas por que fazê-lo antes de ser coroado no Vaticano? Ademais, terminada a coroação, ocorria uma procissão de volta a Latrão, uma segunda posse, diz Boureau, que "priva de sentido a primeira, que nada acrescenta ao evento". ${ }^{47}$ Justamente por isso, é preciso ver outra coisa no rito de Latrão. Assim como a sedes stercoraria, as sellae porphyreticae eram usadas apenas quando da legitimação de um novo papa. Logo após ter se levantado delas o papa entrava no oratório desde Leão IV chamado Sancta Sanctorum devido às suas muitas e preciosas relíquias. Como NON EST IN TOTO SANCTIOR ORBE LOCVS segundo uma inscrição, ali só se entrava com autori-

Paris, Ernest Leroux, 1911, pp. 158 e 188; DUCHESNE, Liber Pontificalis (cit. n. 10), vol. II, p. 306, n. 4. DÖLLINGER, Die Papst-Fabeln (cit. n. 2), por sua vez, pelo fato de as cadeiras porphyreticae terem sido encontradas em um banho público, conclui que esta tinha sido sua função primitiva e que elas foram utilizadas no rito de Latrão por sua antiguidade e pela beleza do mármore, sendo "fortuito" o grande recorte no assento (p. 30). Essa mesma explicação arbitrária foi adotada por autores que baseiam o uso das cadeiras não na sua forma, mas ou no seu valor material (VERNET, col. 1262; VACANDARD, p. 24, citados na nota 1), ou "na sua simbólica cor e bela execução" (DEÉR, The dynastic porphyry [cit. n. 40], p. 144), ou na "sua evidente beleza e esplendor" (PARDOE, A papisa [cit. n. 18], p. 73). Mesmo um estudioso do porte de BAGLIANI aceita a hipótese de cadeiras de banho devido à "verossímel" procedência delas das termas vizinhas (II corpo, cit. n. 31, p. 44; Le chiavi e la tiara. Immagini e simboli del papato medievale, Roma, Viella, 1998, p. 65). Um especialista atual, contudo, F. GANDOLFO, "Cattedra", Enciclopedia dell'Arte Medievale, Roma, Istituto della Enciclopedia Italiana, 1993, vol. IV, considera as sedes porphyreticae efetivamente cadeiras de parturientes que estabeleciam laços entre o papa e a Mater Ecclesia (p. 503).

${ }^{45}$ MACCARRONE, "La cathedra" (cit. n. 40), p. 404, n. 200. Não é dado neutro a condição eclesiástica desse estudioso, tampouco que ele tenha sido nomeado pelo papa Paulo VI presidente da comissão encarregada em 1968 de estudar o trono da Basílica Vaticana conhecido por cátedra de São Pedro. Quando ele rotula a tese de D'Onofrio de monstrum theologicum (p. 405), não é pela mesma razão ideológica que levara DÖLLINGER, Die Papst-Falben (cit. n. 2) a qualificar o relato sobre Joana de Monströseste (p. 20) e Täuschung (p. 31)?

${ }^{46}$ BAGLIANI, II trono (cit. n. 37), p. 167.

${ }^{47}$ BOUREAU, La Papesse (cit. n. 4), p. 102. 
zação pontifícia e o povo romano acreditava que Elias e Enoque lá estavam à espera do Fim dos tempos, ${ }^{48}$ ou seja, o imaginário popular identificava aquele espaço com o Paraíso terrestre. Seus altares laterais abrigavam fragmentos dos quatro grandes santos patronos de Roma (Pedro, Paulo, Inês e Lourenço), enquanto diante de um ícone achéropite ("feito por mão não humana") estava o altar central com relíquias do Cristo e no qual somente o papa podia rezar missa. ${ }^{49}$ Enfim, tudo indica que eram as sedes perforatae que efetivamente transformavam alguém em sumo pontífice. Por que?

Que aquelas cadeiras fossem ou de parturientes ou de banho, em ambos os casos tinham inegável conotação sexual, da mesma forma que os símbolos ali recebidos, a férula e as chaves de função fálica, o cinto vermelho com bolsa púrpura contendo selos e um pequeno frasco com substância odorífera (muscus), objetos e cor alusivos à fisiologia feminina. Os primeiros objetos eram recebidos na cadeira do lado direito, de tradicional significado sexual masculino, e os segundos na da esquerda, lado associado ao feminino. ${ }^{50}$ Se a partir de 1273 a seqüência ritual foi invertida, com a cerimônia de coroação ganhando maior importância e autonomia, isso se deveu às condições políticas do papado de então, que impunham grande mobilidade: dos sete papas do século XIII, seis foram escolhidos fora de Roma. ${ }^{51}$ Portanto, o rito das cadeiras pórfiras foi essencial por pelo menos século e meio. A razão, de acordo com nossa hipótese, estava no fato de que sentar sucessivamente em ambas, primeiro na da direita, depois na da esquerda, com os respectivos símbolos, era androginização simbólica. ${ }^{52}$

${ }^{48}$ F. JUBARU, "Le chef de sainte Agnès au trésor du Sancta Sanctorum", Études (Paris), 42, 1905, p. 722.

49 A lista de relíquias é fornecida por H. GRISAR, Die römische Kapelle Sancta Sanctorum und ihr schatz, Friburgo, Herder, 1908, pp. 89-112, 133-143, e H. LECLERCQ, "Latran”, em Dictionnaire d'archéologie chrétienne et de liturgie, Paris, Letouzey et Ané, 1929, vol. VIII-2, col. 1612-1647.

${ }^{50}$ A posição das cadeiras e os símbolos entregues ao papa estão descritos no Liber censuum (cit. n. 35): Ordo de Cencius, LVIII, vol. 1, pp. 311-313; Ordo de Albino, III, vol. 2, pp. 123-125. As associações direito/masculino e esquerdo/feminino são antigas e difundidas, estando presentes em pelo menos um tipo de fonte acessível aos liturgistas romanos: nos tratados médicos greco-romanos o feto masculino forma-se quando o esperma saído do testículo direito do pai instala-se no lado direito do útero materno, cf. A. ROUSSELLE, Pornéia. Sexualidade e amor no mundo antigo [1983], trad., São Paulo, Brasiliense, 1984, p. 62. Ao contrário do báculo episcopal e abacial, cuja extremidade superior é em voluta, a férula papal é reta.

${ }^{51}$ BAGLIANI, II trono (cit. n. 37), p. 20. No século XIII, é depois da coroação no Vaticano que a procissão papal dirige-se a Latrão, em cujo pórtico o pontífice senta na stercoraria, depois no interior da basílica na magna sede atrás do altar e por fim na entrada da igreja de São Silvestre nas due sedes porphirice, cf. Le Pontifical de la Curie (cit. n. 43), XIII B, 35-47, pp. 114-116.

52 É expressivo que na cerimônia de fins do século XI o papa recebesse a bolsa com as chaves e os selos em uma cadeira e a férula na outra (Liber Pontificalis [cit. n. 10], CLXI, vol. II, p. 296), enquanto com a revalorização da androginia a cerimônia do século XII fazia o bastão e as chaves serem recebidos na primeira cadeira e levados para a segunda, onde eram devolvidos ao oficiante para somente então o papa receber os novos atributos (cf. nota anterior). No século XIII, porém, o pontífice devolve a férula e 
O novo pontífice submetia-se a esse rito de passagem na porta da capela de São Silvestre, fora portanto do espaço sagrado (pro fanum, "diante do templo"), para poder no domingo seguinte, simbolicamente transformado, ser coroado no Vaticano e fazer a cavalgada triunfal que através de Roma o levava de volta à residência lateranense. Talvez não seja sem interesse lembrar que a fase ritual da stercoraria ocorria ao nível do solo, bem de acordo com as palavras que a acompanhavam (pulvere, stercore), enquanto a etapa das pórfiras acontecia depois de o papa ter subido - e conhece-se bem o simbolismo baixo/alto para a Idade Média - longa escada que o conduzia ao andar superior do palácio onde se localizava a referida capela. Boureau, com bons argumentos, vê na postura corporal do papa nas cadeiras pórfiras (inter duos lectulos jacere) um sentido mortuário, ${ }^{53}$ o que no entanto não exclui, pelo contrário reforça, o sentido androginizador do ritual. É a morte que supera os limites terrenos e permite a recuperação da androginia primordial. ${ }^{54}$ O papa era, sem dúvida, visto como andrógino, daí a definição que dele deu Gofredo de Vinsauf em 1210: "nem Deus nem homem, quase neutro entre um e outro". 55

Papel sexual simbólico que resultava do entrecruzamento de várias analogias bem enraizadas na cultura cristã da segunda metade do século XI.

\section{A androginia papal}

A primeira analogia, base das demais, era com a androginia divina, a face feminina da Divindade tradicionalmente representada masculina. É expressivo que ao contrário do original hebraico e da tradução grega, a versão latina bíblica de uma passagem do Antigo Testamento atribua a Deus as expressões "meu útero" e "minha vulva". Um apócrifo do século II fala em Deus Pai com "seios cheios", "ordenhados" pelo Espírito Santo para que

as chaves antes de sentar na segunda cadeira (Le Pontifical de la Curie [cit. n. 43], XIII B, 49, pp. 116-117): indício de novo momento, no qual o sentido anterior do rito perdia força e os atributos específicos não transitavam mais entre um sexo e outro? Talvez, mas ainda não o suficiente para eliminar o rito das cadeiras pórfiras e seu simbolismo, que continuou sendo praticado até, derradeira vez, a posse de Leão X, em 1513 (na de Pio IV, em 1560, recorreu-se apenas ao da stercoraria). Esta se encontra atualmente no claustro de Latrão, enquanto uma das pórfiras no Museu Vaticano e outra no Louvre.

53 BOUREAU, La Papesse (cit. n. 4), pp. 109-110. Aceita esta interpretação BAGLIANI, I/ corpo (cit. n. 31), p. 46.

54 "Quando vocês fizerem de dois uma só coisa, o interno igual ao externo, o externo como o interno, o alto como o baixo, quando vocês fizerem do macho e da fêmea um único indivíduo, de forma que o masculino não seja macho e o feminino não seja fêmea [...] então vocês entrarão no Reino [de Deus]: Il vangelo di Tommaso, 22, trad. M. Erbetta, em Gli apocrifi del Nuovo Testamento, Casale Monferrato, Marietti, 1975, vol. I, p. 267, linhas 17-23, 26-27.

55 "Non Deus es nec homo: quasi neuter es inter utrumque" : Poetria nova, v. 2068, ed. E. Faral, Les Arts poétiques du XII et XIII siècles, Paris, Champion, 1924, p. 261. 
o Filho beba aquele leite. Outro apócrifo oriental de fins do mesmo século e que conheceria grande sucesso no Ocidente, define Cristo como pai e mãe. O próprio Cristo, na pena de João Crisóstomo, diz-se "irmão, irmã, mãe". Em meados do século IV um bispo dirige-se a Deus chamando-o de "pai e mãe, macho e fêmea". Escoto Erígena pensava em Cristo como andrógino. Anselmo de Cantuária insistia sobre Sua face materna. ${ }^{56} \mathrm{~A}$ função materna de Cristo concretiza-se na Igreja, filha nascida sob forma de sangue e água do flanco do Crucificado dormente, de maneira paralela a seu inverso, Eva, formada do flanco do Adão dormente. ${ }^{57} \mathrm{Na}$ iconografia, é famoso o exemplo da iluminura bíblica do início do século XIII que articula na mesma cena o surgimento de Eva do flanco de Adão e o da Igreja do flanco de Cristo. No século XV, algumas miniaturas anatomizam ainda mais a metáfora e mostram a ferida de Cristo como uma vulva. ${ }^{58}$

A segunda analogia transpunha a interpretação judaica de o Cântico dos cânticos como imagem do amor entre lavé e Israel, para Cristo e sua Igreja, modelo de amor conjugal..$^{59}$ É dessa relação matrimonial, mas virginal, que decorre a condição da Igreja de mãe de todos os cristãos - imagem que parte da tradição veterotestamentária de personificar Sion como mulher e das referências apostólicas à união nupcial entre Cristo e a Igreja -,

56 Respectivamente, Isaías, XLIX, 1 ("Audite me domus Jacob, et omne residuum domus Israel, qui portamini a meo utero, qui gestamini a mea vulva"); Odes of Salomon, 19, 1-3, ed.-trad. J. H. Charlesworth, em IDEM (dir.), The Old Testament Pseudepigrapha, Garden City (Nova York), Doubleday , 1985, vol. II, p. 752; Gli Atti di Pietro, 39, 21-22 trad. Erbetta (cit. n. 58), vol. II, p. 168; In Mattheum, LXXVI, 5, PG 58, col. 700; bispo Sinésio, Hinos, II, 316 e III, 320, citado por A. WIRTH, Aus orientalischen Chroniken, Frankfurt, Diesterwig, 1894, p. 199; De divisione naturae, II, 8.12.14; V, 20, PL 122, col. 533 A, 540 C-545; 896 B; Orationes, 65, PL 158, col. 981-982.

57 TERTULIANO, De anima, XLIII, 10, ed. A. Gerlo, em Opera montanistica, Turnhout, Brepols, 1954 (Corpus Christianorum Series Latina, 2), p. 847. Muitas fontes a respeito são citadas por S. TROMP, “De nativitate Ecclesiae ex Corde lesu in Cruce", Gregorianum (Roma), 13, 1932, pp. 489-527. Para o período que aqui nos interessa, C. W. BYNUM, "Jesus as mother and abbot as mother: some themes in twelfth-century Cistercian writing", em IDEM, Jesus as mother. Studies in the spirituality of the High Middle Ages, Berkeley, University of California Press, 1982, pp. 110-169. Na iconografia, é interessante comparar o Exultet 1 de Troia (Archivio Capitolare, meados do século XI), no qual à direita do Crucificado está a Virgem de mãos levantadas, com o Exultet 3 (segunda metade do século XII), no qual a Igreja ocupa aquele lugar e com a mesma postura segura o cálice que recolhe o sangue divino.

58 Respectivamente, Bible moralisée, Paris, Bibliothèque Nationale, ms. lat. 11560, fol. 186, e Breviário de Bonne de Luxemburgo, Nova York, The Cloisters, fol. 331, reproduzidos por J. WIRTH, L'Image médiévale: naissance et développements (VI-XV siècles), Paris, Méridiens Klincksieck, 1989, figuras 26 e 51.

592 coríntios XI, 1-3; Efésios V, 21-32; Mateus XXVIII, 20; TERTULIANO, Adversus Marcionem IV, XI, 7-8; V, XII, 6, ed. A. Kroymann, em Opera catholica, Turnhout, Brepols, 1957 (Corpus Christianorum Series Latina, 1), pp. 567 e 701; De monogamia, VIII, 3, ed. E. Dekkers, ibidem, p. 1239; ORÍGENES, In Canticum canticorum, III, 10, PG 13, col. 183 A; JERÔNIMO, In Mattheum, I, IX, 15, PL 26, col. 57 A; HILÁRIO DE POITIERS, In psalm, LXVII, 7; CXXVII, 8; CXXXI, 24, PL 9, col. 446-447, 708 A, 742-743; BERNARDO, Sermones sobre el Cantar de los Cantares, ed. J. Leclercq, trad. I. Aranguren, Madri, BAC, 1987 (Obras completas de San Bernardo, 5). 
idéia concretizada em fins do século II na expressão Mater Ecclesia forjada por Tertuliano. ${ }^{60}$ É interessante notar que em Roma o uso daquela expressão surgiu apenas na segunda metade do século IV, com o papa Damásio, a quem São Jerônimo lembrava numa carta que um discípulo de Santo Irineu, Hipólito, chamava a Igreja de sponsa Christi. ${ }^{61}$ Também no século IV surgiram as primeiras inscrições de MATER ECCLESIA, expressão cujo uso "político" viria apenas mais tarde, com a Doação de Constantino chamando Latrão de "cabeça e vértice de todas as igrejas do universo", com as expressões Palatium Lateranense e Ecclesia romana sendo usadas como sinônimas sob João XV (985-996). ${ }^{62}$

A terceira analogia identificava o papa com a Igreja. Naquele contexto ideológico no qual o conceito de Mater Ecclesia era importante, sendo mesmo uma das expressões prediletas de Gregório VII, ${ }^{63}$ talvez a pretensa maternidade de Joana desempenhasse algum papel. São Bernardo, escrevendo em 1149-1152 a seu antigo discípulo, Eugênio III, insistia que na função de papa ele devia ser "non ut magister, sed ut mater". ${ }^{4}$ Iconograficamente, essa idéia surgiu em uma miniatura de um Exultet italiano reproduzida por D'Onofrio e julgada pouco comprovadora por Boureau, que a considera caso único. ${ }^{65}$ No entanto

${ }^{60}$ Ad martyras, I, 1, ed. E. Dekkers, p. 3; De oratione, II, 6, ed. G. F. Diercks, p. 258; De baptismo, XX, 5, ed. J. G. Ph. Borleffs, p. 295, em Opera catholica (citada nota anterior). Da extensa bibliografia sobre o tema, lembremos apenas os clássicos H. RAHNER, Mater Ecclesia. Lobpreis der Kirche aus dem ersten Jahrtausend christlichen Literatur, Einsiedeln/Colônia, Benziger, 1944; A. MÜLLER, Ecclesia-Maria. Die Einheit Marias und der Kirche, Friburgo, Paulusverlag, 1951 (Paradosis, 5).

${ }^{61}$ JERÔNIMO, Epistolae, XXXVI, 16, PL 22, col. 461. Cf. J. C. PLUMPE, Mater Ecclesia. An inquiry of the concept of the Church as mother in early christianity, Washington, The Catholic University of America Press, 1943, onde se defende que a prática de ver a Igreja como mãe deve ter se originado na Ásia Menor (pp. 123124), região de forte mitraísmo na época.

${ }^{62}$ H. LECLERCQ, "Église", em Dictionnaire d'archéologie chrétienne et de liturgie, vol. IV-2, col. 2230-2238; Constitutum Constantini, XIII, 250-253, ed. H. Fuhrmann, reproduzido em P. de LEO, II Constitutum Constantini: compilazione agiografica del secolo VIII. Note e documenti, Reggio di Calabria, Editori Meridionali Riuniti, 1974, p. 132; LAUER, Le Palais de Latran (cit. n. 44), p. 144. PEDRO DAMIANO, Epistolae, II, 1, PL 144, col. 255 C, retomou os termos caput, mater, vertex. Mesmo em ambiente não romano, a idéia difundiu-se posteriormente, por exemplo com JACQUES DE VITRY, Histoire occidentale, I, ed. J.-F. Hinnebusch, trad. G. Duchet-Suchaux, Paris, Cerf, 1997, p. 61, reconhecendo que "Roma é a cabeça e a mãe dos fiéis".

63 J. VAN LAARHOVEN, “Christianitas et reforme grégorienne", Studi Gregoriani, 6, 1959-1961, pp. 37-45. A coincidência cronológica parece indicar alguma conexão entre as pretensões do papado gregoriano e a figura da papisa, cuja tradição teria se manifestado em meados do século XI (cf. BIANCHI-GIOVINI, Esame critico [cit. n. 1], p. 1) ou teria tido mesmo "uma não desprezível difusão" no tempo de Gregório VII, papa que "certamente" usou as três cadeiras de mármore no rito de empossamento (cf. D'ONOFRIO, Lapapessa, pp. 42, 137).

${ }^{64}$ De consideratione, Prologus, PL 182, col. 728.

65 D'ONOFRIO, fig. 143; BOUREAU, p. 60 (citados na nota 4). 
Paravicini Bagliani lembra dois outros testemunhos interessantes. Embora um mosaico existente em torno de 1200 (e hoje desaparecido) na abside da basílica de São Pedro mostrasse o papa (Inocêncio III) e a Igreja (mulher coroada tendo na mão um estandarte com as chaves de Pedro) frente a frente, como figuras separadas, em fins do século XIII Egídio Romano concluiu da observação daquela cena que se "pode dizer que o papa é a Igreja". Nessa mesma direção, alguns anos mais tarde, no início do século XIV, um desenho de Opicino de Canistri definia o papa como "corpo apostólico da Igreja", como encarnação dela.$^{66}$ Além disso, um gesto litúrgico também indica que o papa é a Igreja: para Lotário de Segni, futuro Inocêncio III, durante a missa a persona papal deve ser beijada em sete partes do corpo, aplicando a ela a tradicional divisão do corpus Ecclesiae. ${ }^{67}$

A quarta analogia aproximava de várias maneiras o pontífice romano da figura de Cristo. No plano eclesiológico, desde meados do século XI, com a Reforma Gregoriana, o tradicional título papal de "vicário de Pedro" foi sendo crescentemente substituído pelo de Vicarius Christi. ${ }^{68}$ No plano teológico, em 1131 ou 1132, São Bernardo recorreu à sugestiva imagem de que o papa é "osso dos seus [de Cristo] ossos e carne de sua carne"; em 1178, quando Alexandre III retornou a Roma, os fiéis viram no seu rosto o rosto de Cristo; no início da década de 1330, enquanto Álvaro Pelágio afirmava que "o papa é de fato o sucessor de Adão, o primeiro homem, e por isso Deus quis que o Vicário de Cristo fosse feito, a título especial, à sua imagem e semelhança", Opicino de Canistri desenhava o primus homo como homo fidelis com formas ao mesmo tempo masculinas e femininas. ${ }^{69}$ No plano litúrgico, a Igreja, além da antiga e bem estabelecida identificação como sponsa Christi, passava ainda a ser esposa do papa, cujo rito de consagração era justamente o matrimônio com ela. ${ }^{70}$ No plano simbólico, desde Gregório Magno o trono papal na abside de São Pedro estava

66 BAGLIANI, Le chiavi (cit. n. 44), pp. 43-47, figuras 6, 7 e 23 (mosaico); citação de Egídio Romano, p. 43; desenho de Opicino (Biblioteca Apostólica Vaticana, Pal. lat. 1993, fol. 17) figura 43 e p. 49.

67 BAGLIANI, // corpo (cit. n. 31), pp. 93-94; IDEM, “En guise d'introduction: le pouvoir pontifical a-t-il besoin des cinq sens?", Micrologus, 10, 2002, p. XI.

68 M. MACCARRONE, Vicarius Christi. Storia del titolo papale, Roma, Facultas theologica pontificii athenaei Lateranensis, 1952; BAGLIANI, I/ corpo, pp. 82-108; /l trono, pp. 27-28; Le chiavi, pp. 43-55. No século XV, mesmo Deus-Pai era representado como papa, dotado de tiara: F. BOESPFLUG, “Dieu en pape. Une singularité de l'art religieuse de la fin du Moyen Age", Revue Mabillon, 63, 1991, pp. 167-205.

69 Respectivamente, BERNARDO, Epistola CXXVI, 6, em Obras completas de San Bernardo (cit. n. 59), vol. 7, pp. 468-469; Liber Pontificalis (cit. n. 10), vol. II, p. 446; ÁLVARO PELÁGIO, De statu et planctu, I, 13, Veneza, 1560, fol. 4, citado por BAGLIANI, // corpo (cit. n. 31), pp. 90, 103 e // trono (cit. n. 37), p. 28; M. BOSKOVITS, "Androgyne", em E. KIRSCHBAUM (dir.), Lexikon der Christlichen Ikonographie, Roma, Herder, 1968, vol. I, col. 118.

${ }^{70}$ Le Pontifical de la Curie (cit. n. 43), XIII B, 18, pp. 108-109. 
cercado por 24 cadeiras, evocando a assembléia escatológica do Apocalipse. ${ }^{71}$ Ou seja, mais do que representação do Cristo, o papa é sua hipóstase. Ele é o Cristo.

Diante disso, a questão não é de quê a Igreja estaria grávida na cerimônia das cadeiras parturientes, mas de quê o papa/Cristo andrógino estaria. E a resposta é evidente: de cristãos, de filhos fiéis destinados a reproduzirem temporariamente na Terra o corpo divino e depois, na eternidade, a fundirem-se definitivamente Nele. Significativamente, no primeiro relato inconteste sobre Joana, o de João de Mailly, a descrição dela oscila entre mulher travestida de homem e homem visto como mulher. O cronista não lhe dá nome, não lhe atribui amante, não esclarece a origem de sua maternidade. Mas a indefinição sexual não era considerada obstáculo para a carreira eclesiástica. O maior canonista do século XII, o bispo Hugoccio, reconheceu em 1188 que um hermafrodita (cuja existência portanto aceitava) com certa predominância masculina poderia ser ordenado sacerdote. ${ }^{72}$ Nada impedia, conseqüentemente, uma pessoa com tal característica de se tornar papa. $\mathrm{Na}$ verdade, como estamos sugerindo, todo pontífice era simbolicamente andrógino, da mesma maneira que a Igreja, feminina pelo lado celeste (como filha e esposa de Cristo) e masculina pelo terreno (fundada pelo Filho do Homem).

Portanto - elemento que articula os três pontos anteriores -, ao contrário do que pode parecer à primeira vista, a narrativa sobre Joana não era anticlerical nem misógina. ${ }^{73}$ Daí Giovanni Boccaccio, por volta de 1360, tê-la incluído no seu livro sobre as mulheres ilustres, reconhecendo nela uma pessoa dedicada a duas virtudes, o amor e o estudo. Daí

71 Como uma das identificações simbólicas do Cristo era com o leão (por exemplo chamado de "leão de Judá": Apocalipse, V, 5), poder-se-ia especular sobre as estátuas mitraicas de corpo humano com cabeça de leão encontradas em locais de residência papal como Óstia e Castel Gandolfo (J. HANSMAN, "A suggested interpretation of the mithraic lion-man figure", em Études mithriaques, Teerã/Liège, Bibliothèque Pahlavi, 1978, pp. 215-227). Teriam elas sido vistas pelos medievais como fusão figurativa do Andrógino enquanto Mitra, Cristo e papa?

72 Summa Decretorum, citada por I. RAMING, Der Ausschluss der Frau vom priesterlichen Amt. Gottgewollte Tradition oder Diskriminierung?, Colônia/Viena, Böhlau, 1973, pp. 105-106. O caráter andrógino de todo sacerdote cristão talvez explique porque no relato mais difundido sobre Joana, o de Martinho Polonês, atribui-se a ela grandes conhecimentos ("diversis scienciis profecit") mas não o da época do parto ("verum tempus partur ignorans"): Chronicon (cit. n. 12), p. 428, linhas 29-30, 33.

73 J. LE GOFF vê Joana como expressão do medo e da recusa da Igreja ao feminino (Héros et merveilles du Moyen Age, Paris, Seuil, 2005, pp. 8, 174-180), mas como tal sentimento é anterior e posterior ao sucesso do mito da papisa, o sentido dele parece-nos que deva ser outro, específico à sua época, como estamos sugerindo no presente ensaio. 
um guia de peregrinos ter afirmado, em torno de 1375, que a papisa estava enterrada na igreja de São Pedro. ${ }^{74}$ Daí a existência da suposta pedra comemorativa colocada no local em que a papisa teria morrido e de onde foi removida por ordem papal apenas, fato expressivo, em fins do século XVI. Daí a interpolação a Martinho Polonês (feita entre 1278 e 1312) fornecer duas informações essenciais: ela estava sepultada na catedral de Óstia, onde fazia muitos milagres (plurima operatur miracula); o bispo daquela cidade (consagrador de todo papa, segundo o pontifical romano) era o filho de Joana. ${ }^{75}$ Mais do que um clérigo produzindo outro no plano biológico, o mito de Joana mostra a própria sociedade eclesiástica auto-reproduzindo-se sem precisar da sociedade laica. Talvez fosse a isso que aludia no século XV uma crônica em alemão, de acordo com a qual a famosa inscrição era "Papa, pai dos pobres, a papisa pariu um pequeno papa". ${ }^{76}$

Segundo nossa hipótese, não é casual que o rito das cadeiras furadas e o mito de Joana tenham surgido com a revalorização da cultura antiga, em fins do século XI ou princípios do seguinte. A primeira utilização das três cadeiras juntas foi em 1099 para alguns estudiosos, ${ }^{77}$ que identificam portanto as sedes curules referidas naquela data com as sedes porphyraticae de 1124. Mas, como plausivelmente já se propôs, a diferente adjetivação empregada pelos autores do Liber Pontificalis em relação às cadeiras deve ter se devido ao fato de as curuis serem uma coisa e as pórfiras outra. ${ }^{78}$ De toda forma, o rito e o mito parecem manifestações complementares de um mesmo fenômeno psico-religioso, a crença na androginia divina e por extensão pontifícia. Crença que começou lentamente

74 Respectivamente De mulieribus claris, 101, ed. V. Zaccaria, em V. BRANCA (ed.), Tutte le opere di Giovanni Boccaccio, Milão, Arnaldo Mondadori, 2.a ed. 1970, vol. 10, pp. 414-419; Mirabilia Romae, ed. E. Parthey, citado por D'ONOFRIO, La papessa (cit. n. 4), p. 69.

75 MARTINHO POLONÊS, Chronicon (cit. n. 12), p. 429, linha 49; Le Pontifical de la Curie (cit. n. 43), XIII B, 6, pp. 104-105.

76 “Papa, pater patrum, peperit papissa papellum": JOÃO STADTWEG, Chronicon vernaculum, ed. G. W. Leibnitz, Scriptorum rerum brunsvicensium, Hanover, Foersteri, 1711, vol. III, p. 265. Não seria talvez desinteressante investigar as possíveis ligações de longa duração entre a atribuição da sepultura de Joana em Óstia e o fato de nesta cidade terem existido dezessete mithraea e de ali terem estado associados o culto de Mitra e o da Magna Mater (H. STUART JONES, "Mithraism”, em J. HASTINGS, ed., Encyclopaedia of Religion and Ethics, Nova York, Charles Scribner's Sons, s/d, vol. VIII, p. 759), este último também de caráter androginizador (cf. MESLIN, "Réalités psychiques" [cit. n. 26], pp. 298-301).

77 F. GANDOLFO, "Simbolismo antiquario e potere papale", Studi romani, 29, 1981, p. 12; D'ONOFRIO, La papessa (cit. n. 4), p. 140; MACCARRONE, "La cathedra" (cit. n. 40), p. 398.

78 DEÉR, The Dynastic Porphyry (cit. n. 40), pp. 145-146. O Liber Pontificalis data o uso ritual das pórfiras de 1124, enquanto as outras referências documentais aparecem somente no fim do século, no Liber Censuum, cuja versão de Albino é de 1189 e a de Cencio Savelli, futuro papa Honório III, de 1192. No entanto ambos tiveram como fonte comum o Ordo romanus elaborado por volta de 1140, e que estaria portanto registrando a liturgia inaugurada em 1124. 
a declinar a partir de fins do século XIII, quando certos cronistas atribuíram às cátedras com amplo orifício a função de atestar a masculinidade pontifícia, utilização que visaria evitar uma nova Joana. ${ }^{79}$ Como aquelas cadeiras eram usadas na cerimônia lateranense há quase dois séculos, a informação não procede; contudo é importante por revelar uma nova postura quanto ao tema. Naquele momento algumas recentes e perigosas associações entre androginia, neoplatonismo, aristotelismo averroísta e heresias levavam a certa demonização de Joana. ${ }^{80}$

Entretanto a redução da metáfora andrógina a mero episódio escabroso ainda demoraria a acontecer. Se o papa eleito em 1276 assumiu o nome de João XXI, embora não tenha existido um "João XX", foi por considerar legítimo o "João VIII" da papisa. Essa antiga hipótese ${ }^{81}$ leva-nos a indagar as razões de ter sido adotado aquele nome para a metáfora da androginia papal: aceitação de que ele de certa forma sintetizava o papado, já que até meados do século XI (quando talvez tenha aparecido a referência a Joana) existiram dezanove papas "João" (contra, em segundo lugar, nove "Bento" e nove "Estêvão")?

Se a resposta for afirmativa, talvez não tenha sido casual o abandono daquele nome a partir do recuo da concepção andrógina. ${ }^{82} \mathrm{Em}$ todo caso, como a Igreja nasceu com

79 A relação foi estabelecida em 1295 por GOFREDO DE COURLON, Chronicon (cit. n. 12), p. 614, linhas 30 -31, ao desenvolver a informação dada quatro anos antes pelo dominicano ROBERTO DE UZĖS sobre as cadeiras "ubi dicitur probari papa, an sit homo": Le Livre de visions, I, 3, ed. J. Bignami-Odier, Archivum Fratrum Praedicatorum (Roma), 25, 1955, p. 274, linhas 15-16.

${ }^{80}$ Como fizeram duas crônicas franciscanas, a Chronica Minor, redigida por volta de 1265 (cit. n. 13), e a Flores Temporum, de c. 1290 (cit. n. 12), para as quais a inscrição PAPA, PATER PATRUM, PAPISSE PANDITO PARTUM reproduzia uma fala do Diabo.

${ }^{81}$ F. SPANHEIM, Histoire de la papesse Jeanne [1691], trad., La Haye, s/ed., 1758, vol. I, p. 286. De outro lado, E. AMANN, "Jean XXI", em Dictionnaire de Théologie Catholique, Paris, Letouzey et Ané, 1924, vol. VIII-1, pretende que o problema de numeração dos papas João "não tem nada a ver com o romance da papisa Joana" (col. 632,). Trata-se de ponto interessante e complexo, porque, apesar de a numeração dos nomes papais ter começado no século $X$, a maior parte dos cronistas que aceitaram a existência de Joana (todos posteriores àquela época) negou-lhe uma numeração. $O$ primeiro a lhe atribuir um numeral parece ter sido, em torno de 1313, BARTOLOMEU DE LUCCA, Historia ecclesiastica (cit. n. 12),

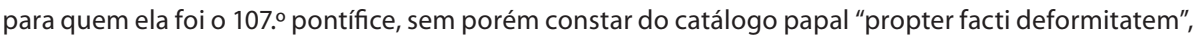
daí porque no ano de 900 um novo João VIII assumiu esse nome como $110 .^{\circ}$ sucessor de Pedro (col. $1013 \mathrm{D}, 1014 \mathrm{AB}, 1018 \mathrm{C})$.

${ }^{82} \mathrm{Na}$ verdade ela sobreviveu na Cúria papal até 1464, data de falecimento do cardeal Nicolau de Cusa, para quem, "é à porta da coincidência dos opostos, guardada por um anjo posto à entrada do Paraíso, que começo a te ver, Senhor" (A visão de Deus, X, ed. L. Gabriel, trad. J. M. André, Lisboa, Calouste Gulbenkian, 1988, p. 169), mas não tendo no contexto cultural renascentista o peso e a significação de antes. Daí talvez o longo intervalo de seis séculos sem um pontífice com aquele nome (João XXII faleceu em 1334, João XXIII assumiu em 1958), que ainda assim continua sendo o mais freqüente na história da Igreja (23, contra 16 ocorrências de Bento e 16 de Gregório). 
uma metáfora proferida pelo próprio Cristo, ${ }^{83}$ não é de estranhar que outras metáforas tenham desenvolvido certos aspectos daquela. A da papisa Joana lembrava que, ao se tornar papa, o indivíduo assumia outra condição, ganhava nova identidade, mudava por isso de nome, passava a ser o sucessor de São Pedro e assim, ritualmente, o Novo Adão, o Cristo simultaneamente pai, mãe e esposo da Igreja, e por conseqüência de todos os fiéis que a compõem.

83 "Tu es Petrus, et super hanc petram aedificato Ecclesiam meam": Mateus XVI, 18. 